Veronika Khalina,

Candidate of Economic Sciences, Associate Professor Kharkiv National University of Civil Engineering and Architecture 40, Sumskaya str., Kharkiv, 61001, Ukraine ORCID: 0000-0001-6753-6414 ResearcherID: AAH-3265-2020

Vyacheslav Butskyi, Candidate of Engineering (PhD), Associate Professor Kharkiv National University of Civil Engineering and Architecture 40, Sumskaya str., Kharkiv, 61001, Ukraine ORCID: 0000-0001-6735-7854

ResearcherID: AAH-4014-2020

Anastasiya Ustilovska, Lecturer Kharkiv National University of Civil Engineering and Architecture 40, Sumskaya str., Kharkiv, 61001, Ukraine ORCID: 0000-0002-9297-7614 ResearcherID: AAH-4274-2020

\title{
MODERNIZATION OF EDUCATIONAL PROGRAMS THROUGH THE INTERDISCIPLINARY APPROACH
}

The article proves the importance of using an interdisciplinary approach as a tool for modernizing curricula. The influence of an interdisciplinary approach on the functioning of socio-economic systems in general is determined. A specific successful example of modernizinga curriculum through the application of an interdisciplinary approach is considered.

Keywords: interdisciplinary approach, curricula, modernization.

Relevance of research topic.An interdisciplinary approach has long proven effective in its educational activities. But today, as never before, it is relevant because of the increased integration and differentiation of knowledge in many spheres and aims to change the very paradigm of social relations in general and the educational system in particular.

Formulation of the problem. The modern world development trends and globalization processes, generational change, emergence of new professions and, accordingly, the need for renewal of human resources lead to changing approaches to educational activity, necessitate transformation of curricula and teaching methods. Interdisciplinarity is recognized as one of the areas of such transformations. 
Analysis of recent researches and publications. The retrospective analysis of the subject of this study demonstrates that the issue of interdisciplinary training has been widely discussed in the United States since the 1890s (Lynn, 1998). Due to researches of Hilda Taba (1966) and other scientists, it became relevantagain since approachesthat focus on studying one discipline do not allow gaining an insight into a certain phenomenon (Jacobs, 1996), looking at it from different angles, objectively evaluating and analyzing the information received. Thus, in the late 1980s, most scientists came to the conclusion that interdisciplinary training can improve the mastery of individual disciplines but not displace them (Concept to classroom: A series of workshops).

Since then, the main task of teachers has been to choose such links among disciplines that can cause higher order thinking, rejecting weak connections that can provoke cognitive dissonance (Jacobs, 1989).

Depending on the nature of relationship among different disciplines within the scope of an integrated program or integrated discipline, the American pedagogical literature distinguishes several types of an interdisciplinary approach: crossdisciplinary approach, which involves considering one discipline through the prism of another; multidisciplinary approach, which implies comparing several disciplines that focus on one problem, without attempting to combine them; pluridisciplinary approach, which involves comparing related disciplines; transdisciplinary approach, which goes beyond individual disciplines, focuses on a certain problem and leads to gaining knowledge in specific fields (Meeth, 1978).

Integrated content-based and skill-based disciplines are particularly effective for forming a set of professional competences of future specialists (Kozolup, 2014).

Presenting main material. The Declaration adopted by the UNESCO'sWorld Conference on Higher Education proclaimed innovativeness, interdisciplinarity and transdisciplinarity to be the principles of modern education. In the guidingdocuments of the Bologna process, interdisciplinarity is considered as a desirable feature of a new quality of higher education (Yakovenko, L).

An interdisciplinary approach has a significant number of advantages, in particular (Olizko, 2015): motivation of students for studyinga certain academic discipline, serious thought and thorough comparison, application of gained knowledge in practice; opportunity to present a well-known material in a new way (Lynn, 1998); broadening students' outlook, increasing theirindependenceand creativity (Solyar\&Beregna); integration of acquired knowledge and skills, perception of material acquired throughout studies as a coherent whole; opportunity to implement the main didactic principles.

Having considered various approaches to understanding the concept of interdisciplinarity (Fig. 1), the authors of this study propose their own definition: interdisciplinarity is the integration of various disciplines in a single cognitive process to deepen, differentiate, diversify knowledge, and skills, due to a wider understanding 
of material and considering it in different ways, and to further generate new ideas with the aim of forming new professional competences and developing research qualities of a student.

\section{Interdisciplinarity is the borrowing and interflow of approaches and methods of different disciplines}

2. Interdisciplinarity is the ability to see, recognize, acquire what was hidden in the depths of an individual science (discipline) using methods and tools of other sciences

(disciplines)

3. Interdisciplinarity in the field of economic research means, on the one hand, takingsocioeconomic, managerial methods, tools beyond the scope of economics itself, and, on the other hand, the interaction of economists with non-economists, borrowing their methodological and applied tools

4. Interdisciplinarity is the extension of interdisciplinary links as a remedy against the overnarrowing of the subject matter, scope of research, problematics of economic disciplines

5. Interdisciplinarity is the borrowing by interconnected sciences (disciplines) of methods, tools, results of research, and constant resorting to their theoretical schemes, models, categories, and concepts

6. Interdisciplinarity is not only a simple borrowing of methods, tools of other sciences (disciplines) but also their integration at the level of designing interdisciplinary objects, subjects, the processing of which allows gaining new scientific knowledge

7. Interdisciplinarity is a scientific and pedagogical innovation that gives rise to the ability to see, recognize, acquire what is not available within an individual science (discipline) with its specific, narrowly oriented object, subject, and research methods

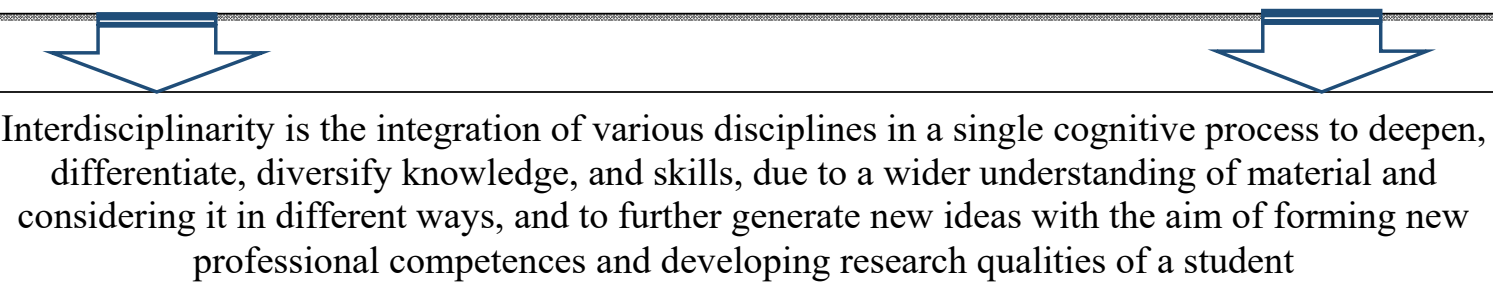

Fig. 1. Definitions of the concept «interdisciplinarity»including the authors' definition 
The educational process based on an interdisciplinary approach makes it possible to form a new generation of specialists who are able not only to perform their functional duties at a qualitatively new level but also to think more broadly and multidimensionally. In general, this development direction will notonly give an impetus for transformation to individual enterprises, organizations and institutions but will also enrich social relations and change their vector (Fig. 2).

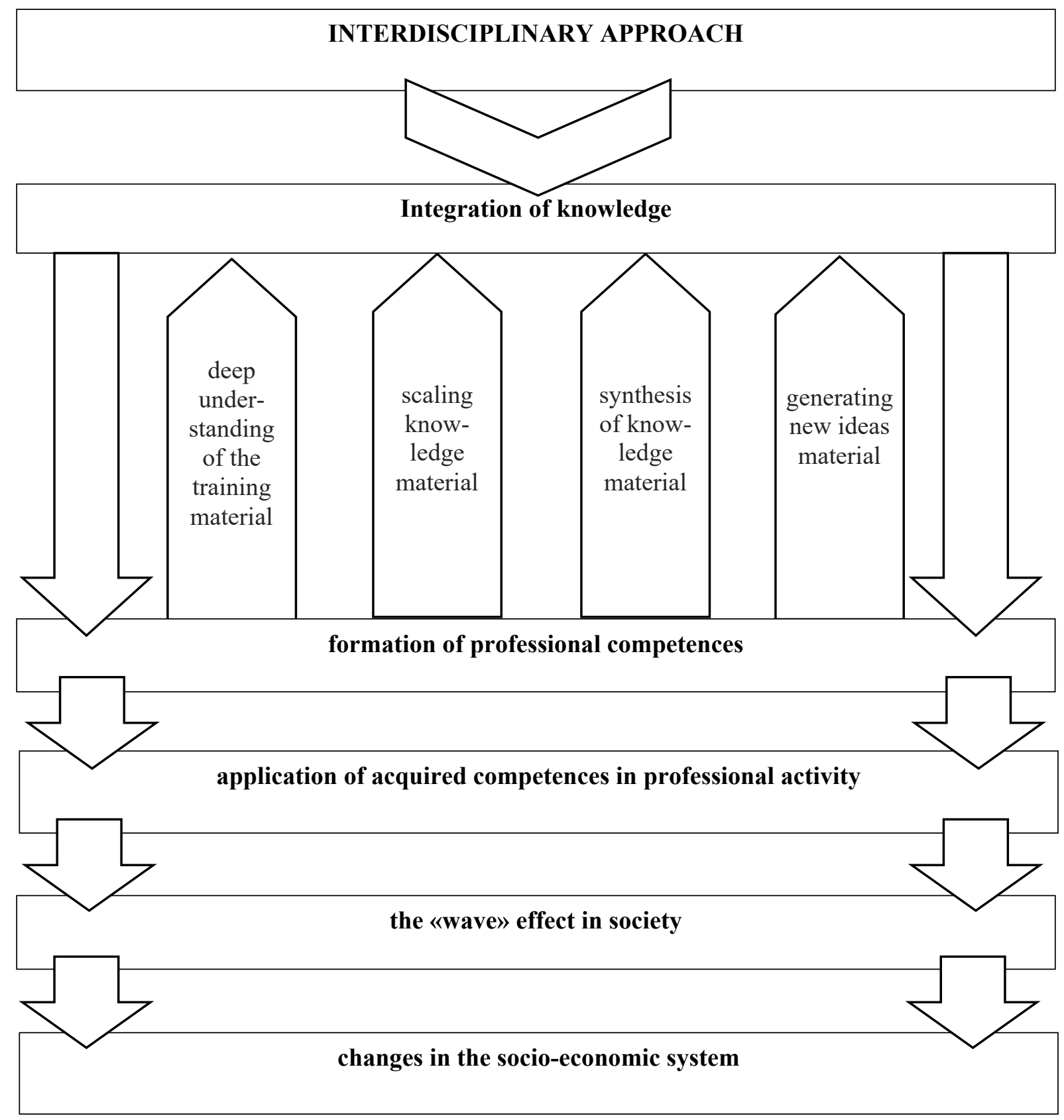

Fig. 2. Impact of a multidisciplinary approach on the functioning of the socio-economic system (compiled by the authors) 
The integration of knowledge of different disciplines, according to the authors of this study, has four main dimensions: a deep understanding of educational material (since through the prism of one discipline, some aspects of another one become more understandable), scaling of knowledge (implying quantitative change and preference for knowledge in a certain area), synthesis of knowledge (combining and coorganizing knowledge into a single system), and generation of new ideas (the studying of material at the intersection of disciplines changes the way we look at familiar things and transforms the cognitive process as a whole).

The result of the mentioned processes is the formation of professional competences of a new level, the use of which will not only lead to an improvement in specialists' fulfilling their professional duties but can change the public mood, creating a «wave» effect concerning certain acute social problems. This results in changes in the socio-economic system of a certain level, and sometimes its complete restructuring or transformation into another one

For example, teaching the academic discipline «Public Procurement and Tenders in the Construction Industry», as part of one of the curricula at the Kharkiv National University of Civil Engineering and Architecture, is based on an interdisciplinary approach, forms students' understanding of procurement processes from an economic, legal, managerial point of view and the understanding of the construction process from a technical point of view. This not only ensures the formation of competences of a specialist in the field of procurement in the generally accepted sense but also expands and enriches them with knowledge and skills specific to the construction industry. In this case,the main message to society will be the popularization of the underlying principles of public procurement, which is intended to change the paradigm of the functioning of the entire system of government orders and its interaction with business in view of the emergence of a new generation of specialists.

Conclusion. Thus, in addition to the above mentioned, an interdisciplinary approach promotes the implementation of didactic principles, stimulates a teacher to update the syllabus content and enrich it with relevant interdisciplinary topics, cases and situations that require integration of knowledge. Therefore, it can be argued that an interdisciplinary approach, based on a multi-year thorough research, forms a new cognitive paradigm in the modern educational system and is in line with world educational trends. 


\section{REFERENCES}

1. Jacobs, H. (1989). The Growing Need for Interdisciplinary Curriculum Content, Interdisciplinary curriculum: Design and implementation, Alexandria, VA: ASDC, p. 5-19.

2. Jacobs, H. (1996). Breaking Ranks: Changing an American Institution Content, Reston, Va.: National Association of Secondary School Principals, P. 56.

3. Kolot, A. (2014). An Interdisciplinary Approach as a Dominant in the Development of Economic Science and Education, Social Economy, Vol. 1-2, pp. 76-83. Retrieved from: http://nbuv.gov.ua/UJRN/se_2014_1-2_15.

4. Kozolup, M. (2014). An Interdisciplinary Approach to Forming Academic Communicative Competence in Natural Sciences Students at US Universities, Pedagogy, Social work, Vol. 30, P. 60. Retrieved from: http://dspace.uzhnu.edu.ua.

5. Lynn, H. (1998). Concept-Based Curriculum and Instruction, Thousand Oaks, Calif.: Corwin Press, P. 192.

6. Meeth, L. (1978). Interdisciplinary Studies: Integration of Knowledge and Experience, Change. Vol. 10, p. 6-9.

7. Olizko, Yu. (2015). An interdisciplinary approach as a means of implementing the basic didactic principles of teaching, Pedagogical discourse, Vol. 18, Retrieved from: http://nbuv.gov.ua/UJRN/0peddysk_2015_18_34

8. Solyar, L., Beregna, G. Implementation of interdisciplinary connections in the study of special subjects of the specialty «Food production». Retrieved from: http://mino.esrae.ru

9. What are the roots of interdisciplinary learning, and how has it evolved over time? Concept to classroom: A series of workshops. - Thirteen New York Public Media. Retrieved from: http://www.thirteen.org/edonline/concept2class/interdisciplina ry/index_sub1.html

10. Yakovenko, L.Interdisciplinarity and the need for its implementation in education. Retrieved from: http://dspace.pnpu.edu.ua 